\title{
Sustainable logistics - a direction of counteracting development problems in cities on the example of Oświęcim
}

\author{
Krystyna Paprzyca \\ https://orcid.org/0000-0003-0112-1456 \\ kpaprzyca@gmail.com, kpaprzyca@pk.edu.pl \\ Katedra Kształtowania Środowiska Mieszkaniowego, Instytut Projektowania \\ Urbanistycznego, Wydziat Architektury, Politechnika Krakowska
}

\begin{abstract}
Summary: The technical infrastructure is one of the essential elements of the system associated with the idea of sustainable development. Urban transport is one of the components of technical infrastructure, and its quality and intensity are often a consequence of "urban sprawl". The phenomenon of uncontrolled spread of the city is currently encountered in many urban centres. It increases the length and time for travels and therefore transport costs. This phenomenon can also have many other negative consequences: - excessive use of land for communication purposes, - the increase of exhaust emission, - the increase in costs related to the use of the car, - the increase of noise on the streets, - increased number of road accidents, - social costs which include lack of exercise, sedentary lifestyle etc. There are various solutions proposed worldwide, the aim of which is to reduce the number of kilometres travelled by car. Such activities are possible due to all initiatives related to changing lifestyles that are introduced and supported by local government units in cities and municipalities. The goal of all actions aimed at efficient urban transport is to create an economically effective system that also reduces the nuisance to the environment. The problems related to the redesigning of existing streets are focused in particular on safety and limiting traffic. The efficient urban transport system is integrated with the issues related to the close neighbourhood and multi-model solutions connected with the choice of means of transport, as well as the high quality of public spaces and the quality of life of residents. The article discusses the above course of action on the example of the city of Oświęcim.
\end{abstract}

Keywords: sustainable development, sustainable city management, sustainable urban design, sustainable urban transport

\section{Introduction}

Technical development, urbanization and lifestyle changes, in small towns and cities in Poland have brought many disadvantageous phenomena such as uncontrolled development, poor housing conditions, inefficient communication system, as well as unemployment, poverty, social pathologies, lack of neighbourhood ties, etc.

Half a century ago, an outstanding Austrian architect - urbanist Roland Rainer formulated the "criteria of a residential city." Unfortunately, he did not realize that the issue of "the quality of urban space " will be the subject of endless discussions that take place between specialists of various fields. Based on the analysis of the development of European cities from the 1960s and 70s of the last century Reiner wrote about the damage caused by the areas of housing estates - the so-called bedrooms.

As a result of the political transformation that took place in Poland in 1989, the country underwent great social and economic changes. They were also reflected in transformations related to urban space and the form of architecture. The processes that had a particular impact on the urban space included: property rights that contributed to the liberation of the free market as well as the free circulation of real estate and mortgage loans or changes related to the investment system.

These processes resulted in the degradation of urban space, as well as the inefficient communication system. Many cities in Poland have suffered from the chaotic implementation of new housing complexes 


\section{Sustainable development in the cities}

The principles of sustainable development that concern the management of the space have been applied, in order to secure adequate living conditions for a man not only today but also for future generations. $[1,2,8]$

The idea of 'sustainable development' means striving to harmonize, balance and coordinate three factors: social development, economic development and the environment.

There are many documents that relate to the policy of sustainable development.

- 1987 The Brundtland Report (World Commission on Economic Development, was the first global attempt addressed to the problems of sustainability.

n 3-14 June 1992 "The Earth Summit" "Environment and Development" conference of the United Nations in Rio de Janeiro,

- 1994 The Alborg Charter, which was created under the influence of the first European conference, also addressed the subject of sustainable development,

- 3-14 June 1996 the United Nations Conference on Human Habitats, HABITAT II, in Istanbul, Konferencji Narodów Zjednoczonych w Sprawie Osiedli Ludzkich HABITAT II, w Istanbul.

The document which set the directions related to the principles of sustainable development was Agenda 21 adopted at the $2^{\text {nd }}$ Conference called "Environment and Development" organized by the UN in Rio De Janeiro in 1992. Its assumptions facilitated the formation of a document created in 1999, which also referred directly to the architecture and which defined the final assumptions of the Agenda - "Agenda 21 on sustainable construction". $[1,6,8]$

All of these reports underline the importance of promoting sustainable development and improving the quality of life and the environment of the European cities.

Cities are the first economic and spatial unit that has an environmental impact. Hence, achieving sustainability at the urban level is a decisive factor.

The tasks related to sustainable development should include, among others:

- sustainable city management,

- sustainable urban design

- sustainable construction,

- sustainable urban transport. [13]

Sustainable city management is essential when striving for a high quality healthy urban environment. It is related to the aspects of energy use, greenhouse gas emissions, water consumption and treatment, waste, noise, air quality, transport and sustainable construction [13].

Sustainable urban transport focuses on growing problems in relation to the urban spread and the increase in transport intensity. According to the data, the length and time devoted to travel, traffic congestion, energy consumption, noise emissions, as well as increasing social and individual transport costs are growing. These problems are the cause of many negative consequences for the urban environment:

- excessive use of land for communication purposes,

- streets congestion, which adversely affects their mobility,

- promotion of a sedentary lifestyle, which in turn leads to diseases and an increase in the cost of benefits

- an increased number of road accidents. etc. [13].

As a consequence, it became popular to promote a model of a compact city, also called a city of short distances. $[7,10]$

This concept promotes the use of a relatively high density of buildings and functional diversity in a given area. Great attention is paid to the efficient public transport system, which may lead to the resignation of car communication. The compact urban layout is always conducive to walking and cycling.

The technical infrastructure is one of the most important systems associated with a compact, modern, sustainable city. Various solutions are promoted in cities around the world, the aim of which is to reduce the number of kilometres travelled by car. It is achievable through the promotion of lifestyle changes. 


\section{Road infrastructure in cities}

The development of public transport is one of the priorities in transport policy adopted by the European Union. The goals include the reduction of $\mathrm{CO}_{2}$ emissions and the improvement of the living conditions in cities. The tasks are aimed at encouraging the use of public transport. These rules were formulated in the Regulation (WE0 1370/2007) in the field of public services as well as rail and road passenger transport. In Poland, this subject is regulated by the Act on Public Collective Transport of December 2010, which defines the role of local government units in the process of shaping public services in collective transport. The main obligation within the framework of planning is the adoption of plans for sustainable development of public mass transport, which is an act of local law. [16 p. 5, 6]

The aim of transport policy is to create conditions for efficient, economically effective movement of people and goods, that limits the negative environmental impact. It can be achieved by ensuring balance in the use of passenger cars and public transport. It is also about introducing facilitations for bicycle and pedestrian traffic while meeting the requirements of reducing the adverse effects of transport for the environment.

While developing communication plans in the Netherlands and many Western European countries, particular attention is paid to the problem of appropriate connections to different places inside and outside of the city. These models are aimed at choosing the best possible access to specific places, by promoting public transport (bus, tram), as well as cycling or walking. $[3,4,5]$

Interdisciplinary activities designed for managing the city's logistics should also be reflected in urban development. Parking buffers, also known as park and go parking, which are usually located the main entrances to the city are needed. Such car parks limit the entry of passenger cars and others to the centre. It is one of the tools necessary to solve the limitations of parking spaces in the central zones of the cities: both in places designated in the main street, as well as in car parks.

Such actions will bring the desired effect only together with the introduction of efficient and effective collective communication connecting destinations with car parks.

In the Netherlands, since the early 1970s, cities planned to reduce the speed through the concept of residential streets with priorities for cycling or pedestrian spaces, and playgrounds for children. (Ministry of Housing Physical Planning and Environment 1983)

There are some obstacles in urban areas that are associated with the improper use of roads, excessive speed, and a high number of "extended" parking.

In order to improve the quality of the urban environment, in the Netherlands and in many European cities, the demand for parking spaces for residents of a given district is precisely described. For example, in 1997 in renewed Schilderswijk district of Hague, it amounted to 0.8 parking spaces per flat, while in the old buildings this coefficient amounted to 0.5 parking space per flat.

There are also parking spaces for parking during the day and at night. (in the day about $50 \%$ of the number of inhabitants require parking spaces, free from the needs of shops and other functions). $[3,4,5]$

The limitation of traffic is also associated with a decrease in noise. The maximum load approved by the Ministry of Health and Hygiene in 1997 (Vollsgezondheid en Milieuhygiene) was $70+5 \mathrm{db} .[3,4]$

It is now necessary to conduct some kind of modernization of previously planned urban layouts.

In order to counteract these problems, it is crucial to develop a comprehensive traffic management strategy, which foresees the minimization of individual communication for collective transport.

To establish this strategy, certain objectives should be adopted:

- establishing zones of diverse communication solutions,

- defining the main groups of users,

- defining the principles of organization and traffic management solutions,

- determination of the impact of these principles on the functioning of the city's transport system and directions of its development

- indication of improving the system in the field of road communication. $[6,9,11]$ 


\section{The plan for sustainable transport development - Oświęcim}

The Oświęcim county was created in 1920 and is one of the oldest self-government units in independent Poland. It is a sub-region of Western Małopolska, characterized by a relatively strong economic position and high standard of living and education of its inhabitants. It has over 800 years of history. [16 p. 11]

Oświęcim is the capital of the county, located in the Małopolska voivodship. It is situated in close proximity to important economic regions: the Kraków agglomeration, the Upper Silesian Industrial District, and the city of Bielsko-Biała. Counties bordering the Małopolska voivodship and Śląskie voivodship are characterized by the highest population density in the country and high transport parameters (length of public roads, length of the public transport lines, usage of public transport, etc.) [16 p. 10.]

The city of Oświęcim is inhabited by around 40,000 people and it is an important industrial centre, dominated by the chemical industry, followed by the mechanical and electromechanical industries, and the production of building materials. As a result of the political transformation that took place in 1989, there was an increase in the competitiveness of many industries, including chemical ones. The restructuring processes of the plant led to a decrease in the areas that were occupied by the chemical industry - first Zakłady Chemiczne in Oświęcim, and later Dwory Chemical Company. Problems that arose as a result of the decline in employment in chemical plants, related to the redundancies of the town's inhabitants and the surrounding areas, were counteracted by mines located close to the city: Brzeszcze, Piast, Libiąż, and the vicinity of the Economic Zone in Tychy, with Fiat Factory.

In response to these negative phenomena, slowing down the growth of the city, local governments began to develop initiatives which were focused on the formation of new jobs, and on the expansion of local entrepreneurship. As a result, the Municipal Economic Activity Zone (MSAG) appeared, which occupies the terrains of former Chemical Plants (today Synthos) as well as the Oświęcim Business Incubator. [14, 15]

The favourable investment climate of the city of Oświęcim is not without a significance for the growth of its income, which in turn affects the quality of public services and economic progress.

The indicator of change in the number of inhabitants in the area of Oświęcim is similar to the rate of change in the number of residents throughout Poland $(+0.84 \%)$ The increase in population in areas nearby the city shows that the process of suburbanization can be observed also in Oświęcim. It is a generator of increased demand for efficient collective transport, which will connect the city centre with newly established settlements located in the periphery. [16 p. 18.] An adverse demographic tendency observed in the region is the ageing of the inhabitants, that is people in the post-working age, which has an impact on the reduction of the offer of public transport.

Other indicators that may show growing dynamics of the city's development are the remuneration index, which in 2012 amounted to $87.3 \%$ of the national average. [16 p. 22]

According to statistical data, over the period of $2009-13$ [16 p. 28], the number of private cars increased by over $15 \%$. However, the automotive indicator does not have to translate into an increased number of journeys made with private cars.

Investments related to road transport are a priority because they translate into the quality of life of both residents and people coming to the city. The most important undertakings that have been comprised in relevant municipal spatial development plans include, among others, improving access for disabled people by lowering curbs, slipways, special places for handicapped people, modernizing and developing urban street networks, extending them and equipping them with roadsides, bays, and proper pavements drainage, modernization of intersections, improvement of signage, creation of a car park system and parking bays, which will be connected with the collective transport, construction of bicycle routes and places for leaving bicycles and many other activities. Improving the attractiveness of public transport (vehicle standard and their aesthetics). [12, 13, 14]

There are many other very important investments planned, which in a meaningful way will improve the quality of life and residence. 


\section{Conclusion}

Continuous use of a car in our country, instead of walking or cycling or using public transport means that people are completely addicted to cars. As a consequence, we suffer from numerous diseases. According to the data from 2001, the average American family travels nearly as many kilometres as the perimeter of the Earth. The saddest part is that these distances are achieved by getting to work, school or doing shopping. According to the studies carried out by the National Institute of Health, obesity and other effects of an inactive lifestyle contribute to a 5-year reduction in life expectancy per one American. And the rest of the world, including Poland, goes in the same direction. This American pattern related to lifestyle will probably continue in the future.

Governments and economies should act as soon as possible to introduce the most energy efficient technologies that contribute to reducing not only the costs of car driving but also to reduce environmental pollution. The only cost-effective method associated with climate change, improvement of public health and a better sense of well-being, and related to the transport sector, is to reduce the kilometres travelled by American families

\section{References}

[1] ISO 14040 - Environmental management - Life cycle assessment - principles and framework, First Editio, 1997.06.15.

[2] Environmental management, Polskie Wydawnictwo Ekonomiczne S.A. Warsaw 00-099, ul. Canaletta 4.

[3] Main characteristics of the land - use Policy In the Netherlands, Minister of Housing and Physical Planning, The Hague, 1994.

[4] Stadsvernieuwing s'Gravenage 1975-1984, Gemente s'Gravenhage, The Hague 1984 Statistics on Housing and construction In the Netherlands, Neth. J. of Housing and the Butli Environment, Vol 9 (1994) No 1.

[5] Statistics on housing and construction In the Netherlands, Neth. J. of Housing and the Built Environment, Vol 9 (1994) No 1.

[6] S. Gzell, Urban planning as one of the tools to balance urban development - an example of Warsaw and Berlin squares, Sustained development of Polish cities a new challenge for planning and managing space, Ewa Heczko-Hyłowa, Cracow University of Technology, Kraków 2001.

[7] R.G. Ridker, I.A. Henning, The Determinant soft Residential Property Values with Special Reference to Air Pollution, Review of Economics and Statistics, 1967, No 49(2).

[8] New urban planning - a new quality of life, Materials of the III Congress of Polish Urban Planning, Urbanist Library, vol. 14, Warsaw 2009, Public Space Card (edited by L. Biegański, G. Buczek, S. Gzell, A. Kowalewski, T. Markowski, E. Cichy-Pazder).

[9] Paprzyca K., Harmonizing urban development of urban areas - selected issues, Monograph 417, Krakow, Cracow University of Technology 2012.

[10] Paszkowski Z., A perfect city in the European perspective and its connections with contemporary urban planning, KrakOW, UNIVERSITAS 2011.

[11] Urban revitalization in Poland, 2009-2010, Publishing series edited by Z. Ziobrowski, Institute for Urban Development, Krakow.

[12] Development strategy for the city of Oświęcim for years 2014-2020.

\section{Internet sources}

[13] DEVELOPMENT OF ECOLOGICAL ABSORBENCY CRITERIA - PDF Institute of Spatial Management and Housing ul. Targowa 45 03-728 Warszawa, http://docplayer.pl/7597595-Opracowanie-kryteriow-chlonnosci-ekologicznej.html.

[14] http://web.um.oswiecim.pl/strategia-uwagi/strategia_rozwoju_miasta_oswiecim_na_lata_2014-2020.pdf (16.07.2016).

[15] Factors of entrepreneurship development in... - Województwo Małopolskie, www.malopolskie.pl/Pliki/2008/Opracowanie.pdf (16.07.2016).

[16] Plan for sustainable development of public transport... Plan for the sustainable development of public public transport, web.um.oswiecim.pl/bip/dokumenty/pliki/109/24221.pdf. 